\title{
Seasonal Variability of Seaweed Biomass along the Vertical Shore Gradients of Nachido and Odo Islands, the Yellow Sea, Korea
}

\author{
Bo Yeon Kim, Won Sin Kim and Han Gil Choi* \\ Faculty of Biological Science and Research Institute for Basic Science, \\ Wonkwang University, Iksan 570-749, Korea
}

\begin{abstract}
Seasonal variation in seaweed biomass was examined along vertical shore gradients on the rocky shores of Nachido and Odo Islands, the Yellow Sea, Korea, from August 2007 to April 2008. The average annual biomass of seaweed was $404.07 \mathrm{~g}$ wet $\mathrm{wt} / \mathrm{m}^{2}$, with seasonal variation from $232.61 \mathrm{~g}$ in the spring to $754.90 \mathrm{~g}$ wet $\mathrm{wt} / \mathrm{m}^{2}$ in the summer at Nachido Island. At Odo Island, average biomass was $270.82 \mathrm{~g}$ wet $\mathrm{wt} / \mathrm{m}^{2}$ and ranged from $48.35 \mathrm{~g}$ in the winter to $451.66 \mathrm{~g}$ wet wt $/ \mathrm{m}^{2}$ in the spring. Seaweed biomass exhibited an even distribution across the shore gradient from the high intertidal zone to $-5 \mathrm{~m}$ depth at Nachido Island, whereas seaweed biomass was concentrated from the mid intertidal zone to $-1 \mathrm{~m}$ depth in the subtidal zone at Odo Island. Sargassum thunbergii was the most dominant species, occupying $28.24 \%\left(114.12 \mathrm{~g}\right.$ wet $\left.\mathrm{wt} / \mathrm{m}^{2}\right)$ and $36.57 \%\left(99.05 \mathrm{~g}\right.$ wet $\left.\mathrm{wt} / \mathrm{m}^{2}\right)$ of total biomass at Nachido and Odo Islands, respectively. Subdominant seaweed species was Gelidium amansii, comprising $15.23 \%\left(61.52 \mathrm{~g}\right.$ wet $\left.\mathrm{wt} / \mathrm{m}^{2}\right)$ and $14.70 \%\left(39.82 \mathrm{~g}\right.$ wet $\left.\mathrm{wt} / \mathrm{m}^{2}\right)$ of total biomass at Nachido and Odo Islands, respectively. Dominant functional group was the coarsely branched-form group, which grows under moderate environmental conditions and comprised 93.34\% (377.15 g wet wt $\left./ \mathrm{m}^{2}\right)$ and $66.96 \%\left(181.35 \mathrm{~g}\right.$ wet $\left.\mathrm{wt} / \mathrm{m}^{2}\right)$ of total biomass at Nachido and Odo Islands, respectively. Percentage biomass of sheet-form seaweeds growing at relatively disturbed and polluted areas was approximately $20.83 \%\left(56.40 \mathrm{~g}\right.$ wet $\left.\mathrm{wt} / \mathrm{m}^{2}\right)$ of total biomass along the Odo rocky shore. Based on the biomass and functional-form composition of seaweeds, we concluded that Nachido Island provides better environmental conditions than does Odo Island. In addition, the vertical distribution and dominant species of seaweeds on the two islands were very similar, but the functional-form composition of seaweeds at Nachido Island differed slightly from that at Odo Island.
\end{abstract}

Key words: Biomass, Functional form, Nachido, Odo, Seaweed

\section{Introduction}

Seaweeds are a very important component of marine ecosystems because of their ecological roles as primary producers and as providers of habitat, nursery grounds, and food sources for various marine animals (Terawaki et al., 2001; Choi et al., 2002; Eklof et al., 2005). Seaweed community structure, including seaweed biomass and functional-form abundance, changes seasonally and spatially, as it is closely related to environmental factors such as light, seawater temperature, sedimentation, and nutrient availability (Steneck and Dethier, 1994; Piazzi et al., 2002; Arévalo et al., 2007). For example, sheet- and filamentous-forms of green ephemeral seaweeds are

\footnotetext{
*Corresponding author: hgchoi@wku.ac.kr
}

generally prevalent in disturbed and/or eutrophied habitats (Littler and Littler, 1984; Steneck and Dethier, 1994; Pinedo et al., 2007). Conversely, late successional, thick-leathery- and calcareous-form seaweeds are dominant under stable environmental conditions, whereas coarsely branched-form seaweeds typically occur in moderate environments (Littler and Littler, 1984). Thus, the biomass and functional composition of seaweed communities are very important biological parameters that reflect overall environmental conditions (Hay, 1994; Phillips et al., 1997; Ballesteros et al., 2007).

Environmental conditions, such as desiccation, light, and wave action, also change along depth gradients because of the tidal cycle, often along the same rocky shore (Neto, 2001; Díez et al., 2003); thus, vertical differences in species number and biomass of 
seaweeds are expected to occur along such gradients. Light and desiccation stress are very high in the intertidal zone, resulting in lower seaweed biomass compared with the subtidal zone, where light limitation occurs (Steneck and Dethier, 1994). Such environmental gradients result in changing vertical zonation patterns of dominant species, functionalform composition, and seaweed biomass (Konar et al., 2009). For example, Neto (2001) reported that the intertidal zone tends to be populated by single, tolerant species (e.g., Enteromorpha spp.), whereas subtidal rocky shores exhibit higher biodiversity and biomass because of less environmental stress. In the subtidal zone of the Gulf of Maine, seaweeds exhibited distinctive vertical distribution from the uppermost zone (thick leathery seaweed to $40 \mathrm{~m}$ ), through a middle zone (coarsely branched, sheet-like, or filamentous seaweed to $50 \mathrm{~m}$ ), to a deep zone of coralline crustose seaweed inhabiting up to $63 \mathrm{~m}$ depth (Vadas and Steneck, 1988).

In Korea, studies of seaweed communities have primarily focused on the vertical distribution of dominant seaweeds, seasonal biomass variation, and the species composition of intertidal rocky shores (Kim et al., 1995; Yoo et al., 2007; Choi and Huh, 2008). Few studies of subtidal seaweed assemblages have been conducted due to sampling difficulties and the high costs of scuba equipment and boat (Baek et al., 2007; Choi et al., 2008; Ko et al., 2008). In particular, our knowledge of seaweed community structure in both the intertidal and subtidal zones of offshore islands located in the Yellow Sea, Korea, is lacking, with a few recent exceptions (Baek et al., 2007; Choi et al., 2008; Wan et al., 2009). Therefore, the goals of the present study were to examine seasonal biomass variation of rocky-shore seaweeds and their composition in terms of both taxa and functional-form groups along the vertical shore gradients of Nachido and Odo Islands, the Yellow Sea, Korea. Furthermore, we tested the hypotheses that the two islands would exhibit similar vertical patterns in seasonal and functional-form distribution of seaweed biomass.

\section{Materials and Methods}

Seaweed collections were conducted seasonally along the rocky shores of Nachido $\left(36^{\circ} 35^{\prime} \mathrm{N}\right.$, $\left.126^{\circ} 12^{\prime} \mathrm{E}\right)$ and $\mathrm{Odo}\left(36^{\circ} 35^{\prime} \mathrm{N}, 126^{\circ} 03^{\prime} \mathrm{E}\right)$ Islands in the Yellow Sea, Korea, from August 2007 to April 2008. For quantitative data collection, five replicate $50 \times 50$ $\mathrm{cm}$ quadrats were randomly placed in both the intertidal zone (high, middle, and low) and the subtidal zone (-1 $\mathrm{m}$ and $-5 \mathrm{~m}$ depths from the Sargassum fusiforme zone) during low tide. Based on biological characteristics, subtidal shore levels began at the $S$. fusiforme zone in the present study. Subtidal seaweed collections were conducted via SCUBA. All seaweeds within each quadrat were collected using a scraper, placed into plastic bags, preserved in a 5$10 \%$ formalin: seawater solution, and transported to the laboratory.

At the laboratory, seaweeds were rinsed with tap water and identified following the classification and nomenclature of Lee and Kang (2001). Seaweeds from each quadrat were measured for wet weight, and biomass was calculated. All samples were divided into six functional-form groups: sheet, filamentous, coarsely-branched, thick-leathery, jointed-calcareous, and crustose forms (Littler and Littler, 1984); classifications were based on Lee et al. (2007a). In the present study, however, Gracilaria textorii was considered a member of the coarsely-branched form group (versus the thick-leathery form group), which includes a congener (Gracilaria vermiculophylla; Lee et al., 2007a) and the morphologically and anatomically similar Chondrus sp. (Steneck and Dethier, 1994).

\section{Results}

\section{Seasonal variation}

Nachido. Average annual biomass of seaweeds was $404.07 \mathrm{~g}$ wet $\mathrm{wt} / \mathrm{m}^{2}\left(90.02 \mathrm{~g}\right.$ dry $\left.\mathrm{wt} / \mathrm{m}^{2}\right)$, with seasonal variation ranging from $232.61 \mathrm{~g}$ wet $\mathrm{wt} / \mathrm{m}^{2}$ in the spring to $754.90 \mathrm{~g}$ wet $\mathrm{wt} / \mathrm{m}^{2}$ in the summer (Table 1). On the basis of seaweed biomass, Sargassum thunbergii was the most dominant species, occupying $28.24 \%$ of total biomass; Gelidium amansii was subdominant, comprising $15.23 \%$ of total biomass. In the spring, however, G. amansii was extremely abundant, with an average biomass of $43.36 \%$, followed by Sargassum honeri $(28.61 \%)$. The major taxon groups of seaweeds on the Nachido rocky shore were brown and red algae, including four red and three brown algal species with more than $10 \mathrm{~g}$ wet $\mathrm{wt} / \mathrm{m}^{2}$ each in average annual biomass, occupying $88.04 \%$ of total annual biomass (Table 1).

Odo. Average annual seaweed biomass was 270.82 $\mathrm{g} / \mathrm{m}^{2}$ in wet weight $\left(89.13 \mathrm{~g}\right.$ dry $\left.\mathrm{wt} / \mathrm{m}^{2}\right)$. Biomass ranged from $48.53 \mathrm{~g}$ wet $\mathrm{wt} / \mathrm{m}^{2}$ in the winter to $451.66 \mathrm{~g}$ wet $\mathrm{wt} / \mathrm{m}^{2}$ in the spring (Table 1). Similar to Nachido, annual seaweed biomass was composed of S. thunbergii (36.57\%) and G. amansii $(14.70 \%)$. 
Table 1. Seasonal and annual average biomass $\left(\mathrm{g}\right.$ wet $\left.\mathrm{wt} / \mathrm{m}^{2}\right)$ of dominant seaweeds and their percentage $(\%)$ for total biomass (TB) at Nachido and Odo Islands of Yellow Sea, Korea from August 2007 to April 2008

\begin{tabular}{|c|c|c|c|c|c|}
\hline Site/Species & Summer & Autumn & Winter & Spring & Average ( $\%$ of TB) \\
\hline \multicolumn{6}{|l|}{ Nachido } \\
\hline Sargassum thunbergii & 246.91 & 85.76 & 112.50 & 11.30 & $114.12(28.24 \%)$ \\
\hline Gelidium amansii & 93.53 & 17.99 & 33.71 & 100.85 & $61.52(15.23 \%)$ \\
\hline Chondrus ocellatus & 147.31 & 87.54 & 2.31 & 0.06 & $59.31(14.68 \%)$ \\
\hline Sargassum fusiforme & 165.68 & 41.04 & 28.21 & 0.43 & $58.84(14.56 \%)$ \\
\hline Sargassum horneri & - & 24.09 & 48.36 & 66.54 & $34.75(8.60 \%)$ \\
\hline Corallina pilulifera & 27.38 & 10.90 & 29.07 & - & $16.84(4.17 \%)$ \\
\hline Neorhodomela aculeata & 0.05 & 0.05 & 12.71 & 28.59 & $10.35(2.56 \%)$ \\
\hline Pterocladiella cappillacea & 12.41 & 12.41 & 6.44 & - & $7.82(1.94 \%)$ \\
\hline Other algae & 61.63 & 65.76 & 9.91 & 24.84 & $40.54(10.03 \%$ \\
\hline Total & 754.90 & 345.54 & 283.22 & 232.61 & $404.07(100.00 \%)$ \\
\hline \multicolumn{6}{|l|}{ Odo } \\
\hline Sargassum thunbergii & 106.69 & 143.95 & 11.31 & 134.24 & $99.05(36.57 \%)$ \\
\hline Gelidium amansii & 42.84 & 59.84 & 26.40 & 30.21 & $39.82(14.70 \%)$ \\
\hline Scytosiphon lomentaria & - & - & - & 102.90 & $25.72(9.50 \%)$ \\
\hline Gracilaria textorii & 28.79 & 37.93 & 6.21 & 0.86 & $18.45(6.81 \%)$ \\
\hline Corallina pilulifera & 16.48 & 32.56 & 0.05 & 9.15 & $14.56(5.38 \%)$ \\
\hline Chondria crassicaulis & 22.00 & 6.29 & 1.89 & 13.92 & $11.02(4.07 \%)$ \\
\hline Dumontia simplex & - & - & - & 42.91 & $10.73(3.9 \%)$ \\
\hline Undaria pinnatifida & - & - & - & 37.28 & $9.32(3.44 \%)$ \\
\hline Plocamium telfairiae & 16.94 & 15.42 & 1.58 & 1.58 & $8.88(3.28 \%)$ \\
\hline Urospora penicilliformis & - & - & - & 31.17 & $7.79(2.88 \%)$ \\
\hline Sargassum fusiforme & 6.98 & 14.79 & 0.10 & 1.84 & $5.93(2.19 \%)$ \\
\hline Porphyra tenera & - & - & - & 15.93 & $3.98(1.47 \%)$ \\
\hline Other algae & 27.17 & 4.40 & 0.99 & 29.68 & $15.56(5.75 \%)$ \\
\hline Total & 267.89 & 315.20 & 48.53 & 451.66 & $270.82(100.00 \%)$ \\
\hline
\end{tabular}

In winter, G. amansii (54.40\%) reached maximum biomass, followed by $S$. thunbergii (23.31\%). Seasonal seaweeds, such as Scytosiphon lomentaria, Urospora penicilliformis, and Porphyra tenera, were only abundant (biomass more than $15 \mathrm{~g}$ wet $\mathrm{wt} / \mathrm{m}^{2}$ ) in the spring (Table 1). Five red and two brown algal species were major seaweed taxa, exhibiting more than $10 \mathrm{~g}$ wet $\mathrm{wt} / \mathrm{m}^{2}$ each in average annual biomass and together comprising $80.99 \%$ of total annual biomass.

\section{Vertical variation}

Nachido. Average annual seaweed biomass was $408.57 \mathrm{~g}$ wet $\mathrm{wt} / \mathrm{m}^{2}\left(84.32 \mathrm{~g}\right.$ dry $\left.\mathrm{wt} / \mathrm{m}^{2}\right)$ in the intertidal zone, which was similar to the value observed in the subtidal zone $\left(399.57 \mathrm{~g}\right.$ wet $\mathrm{wt} / \mathrm{m}^{2}$; $95.72 \mathrm{~g}$ dry $\mathrm{wt} / \mathrm{m}^{2}$ ). Seasonal variation in seaweed biomass ranged from $141.90 \mathrm{~g}$ wet $\mathrm{wt} / \mathrm{m}^{2}$ in the spring to $898.65 \mathrm{~g}$ wet $\mathrm{wt} / \mathrm{m}^{2}$ in the summer in the intertidal zone; values ranged from $302.51 \mathrm{~g}$ wet $\mathrm{wt} / \mathrm{m}^{2}$ in the winter to $611.16 \mathrm{~g}$ wet $\mathrm{wt} / \mathrm{m}^{2}$ in the summer in the subtidal zone (Fig. 1). The vertical distributions of dominant species based on seaweed biomass are presented in Fig. 2. Seaweed biomass ranged from $326.80 \mathrm{~g}$ wet $\mathrm{wt} / \mathrm{m}^{2}$ at high shore level to

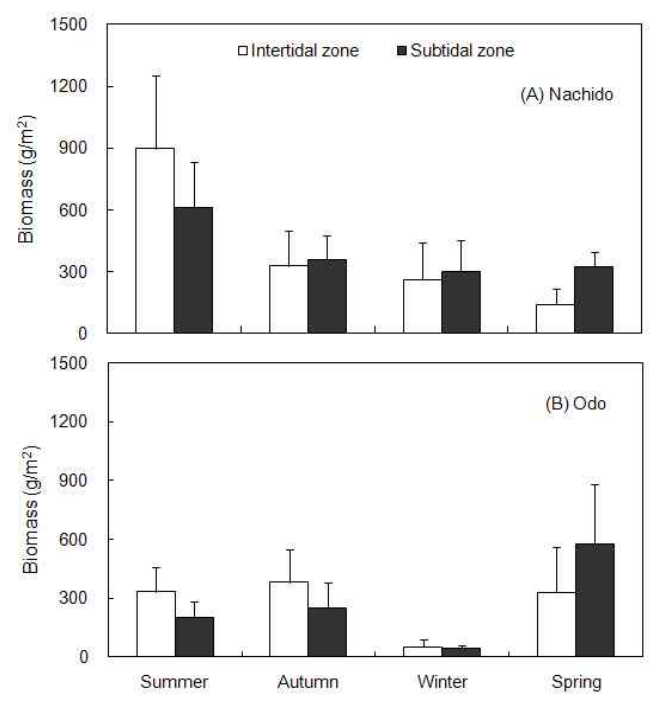

Fig. 1. Seasonal variations in average seaweed biomass $\left(\mathrm{g}\right.$ wet $\left.\mathrm{wt} / \mathrm{m}^{2}\right)$ of intertidal and average subtidal zones at (A) Nachido and (B) Odo Islands, the Yellow Sea, Korea, from August 2007 to April 2008. Vertical bars represent standard errors.

$483.04 \mathrm{~g}$ wet $\mathrm{wt} / \mathrm{m}^{2}$ at middle shore. Brown alga Sargassum thunbergii was the most abundant species in the intertidal zone, whereas G. amansii and 

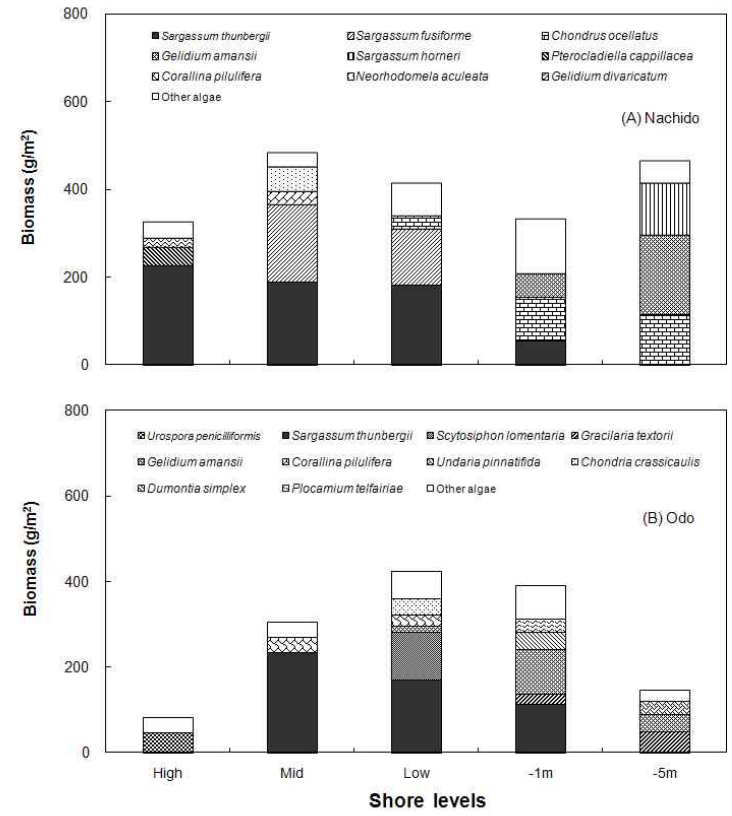

Fig. 2. Vertical distribution of dominant seaweeds in annually-averaged biomass ( $\mathrm{g}$ wet $\mathrm{wt} / \mathrm{m}^{2}$ ) at (A) Nachido and (B) Odo Islands, the Yellow Sea, Korea, from August 2007 to April 2008.

Chondrus ocellatus co-dominated at $-1 \mathrm{~m}$ and $-5 \mathrm{~m}$ depths in the subtidal zone.

Odo. Average seaweed biomass of the intertidal zone $\left(273.11 \mathrm{~g}\right.$ wet $\mathrm{wt} / \mathrm{m}^{2} ; 107.50 \mathrm{~g}$ dry $\left.\mathrm{wt} / \mathrm{m}^{2}\right)$ was similar to that in the subtidal zone $(268.53 \mathrm{~g}$ wet $\mathrm{wt} / \mathrm{m}^{2} ; 70.75 \mathrm{~g}$ dry $\left.\mathrm{wt} / \mathrm{m}^{2}\right)$. Maximum seaweed biomass was recorded in autumn (381.51 $\mathrm{g}$ wet $\mathrm{wt} / \mathrm{m}^{2}$ ), whereas minimum biomass occurred in the winter $\left(50.40 \mathrm{~g}\right.$ wet $\left.\mathrm{wt} / \mathrm{m}^{2}\right)$ in the intertidal zone. In the subtidal zone, annual seaweed biomass ranged from $46.67 \mathrm{~g}$ wet $\mathrm{wt} / \mathrm{m}^{2}$ in the winter to $574.42 \mathrm{~g}$ wet $\mathrm{wt} / \mathrm{m}^{2}$ in the spring (Fig. 1). The vertical distributions of dominant species based on seaweed biomass are presented in Fig. 2. Seaweed biomass fluctuated from $91.30 \mathrm{~g}$ wet wt $/ \mathrm{m}^{2}$ at high shore level to $423.20 \mathrm{~g}$ wet $\mathrm{wt} / \mathrm{m}^{2}$ at low shore level. Sargassum thunbergii was the representative species from the middle shore to -1 m depths, whereas G. amansii and Gracilaria textorii were mainly distributed on the subtidal rocky shore. Notably, Urospora penicilliformis was only reported as the dominant species along the high rocky shore in the spring.

\section{Functional-form groups}

Functional-group diversity included the same five functional-form groups (sheet, filamentous, coarselybranched, thick-leathery, and jointed-calcareous forms) at both Nachido and Odo Islands (Table 2).
Crustose-form seaweeds were observed in summer and autumn at Odo Island, but seaweed biomass was not recorded due to sampling difficulties. During the sampling year, coarsely-branched forms were the most abundant $\left(377.15 \mathrm{~g}\right.$ wet $\left.\mathrm{wt} / \mathrm{m}^{2}\right)$ in terms of biomass, accounting for $93.34 \%$ of total biomass (404.07 $\mathrm{g}$ wet $\mathrm{wt} / \mathrm{m}^{2}$ ) at Nachido Island. At Odo Island, coarsely-branched forms $\left(181.35 \mathrm{~g}\right.$ wet $\mathrm{wt} / \mathrm{m}^{2}$; $66.96 \%)$ and sheet forms $\left(56.40 \mathrm{~g}\right.$ wet $\mathrm{wt} / \mathrm{m}^{2}$; $20.83 \%$ ) were the first- and second-most dominant groups, together accounting for $87.79 \%$ of total biomass $\left(270.82 \mathrm{~g}\right.$ wet $\left.\mathrm{wt} / \mathrm{m}^{2}\right)$. Although annual seaweed biomass was greater along the Nachido shore than along the Odo shore, sheet-form seaweeds (such as Scytosiphon lomentaria) were significantly higher in annual biomass at Odo than at Nachido Island. Coarsely branched-form seaweeds dominated functional-form group biomass at Nachido and Odo Islands during the study period. In the spring, however, sheet-form seaweed biomass $(178.36 \mathrm{~g}$ wet $\mathrm{wt} / \mathrm{m}^{2}$ ) was similar to coarsely branched-form seaweed biomass (192.72 $\mathrm{g}$ wet $\left.\mathrm{wt} / \mathrm{m}^{2}\right)$ at Odo Island.

Vertical abundance of functional-form seaweeds in terms of biomass was related to the dominant algal species. At Nachido, the coarsely-branched form seaweed, Sargassum thunbergii was distributed from the high shore level to $-1 \mathrm{~m}$ depths, Sargassum fusiforme occurred from middle shore to $-1 \mathrm{~m}$ depths, and Chondrus ocellatus and Gelidium amansii were abundant in the subtidal zone. Jointed-calcareous Corallina pilulifera was distri-buted at mid-shore levels. Along the Odo rocky shore, the coarselybranched form species, $S$. thunbergii was abundant from mid shore to $-1 \mathrm{~m}$ depth, and G. amansii was dominant along the subtidal shore. Sheet form seaweeds, Scytosiphon lomentaria (at the low intertidal shore), Dumontia simplex, and Plocamium telfairiae (both at $-1 \mathrm{~m}$ depth) occurred along the Odo rocky shore. Thick leathery-form species Gracilaria textorii (at $-1 \mathrm{~m}$ and $-5 \mathrm{~m}$ depth) and Undaria pinnatifida (at $-5 \mathrm{~m}$ depth) dominated the subtidal zone, and the jointed-calcareous species $C$. pilulifera dominated the intertidal zone. Filamentous green seaweed (Urospora penicilliformis) and sheet form seaweeds, such as Porphyra tenera, Dumontia simplex, and Scytosiphon lomentaria, exhibited similar patterns with more frequent occurrences in the spring.

\section{Discussion}

Seaweed biomass can increase under clean and stable or eutrophied environmental conditions in tem- 
Table 2. Seasonal variations in mean biomass $\left(\mathrm{g}\right.$ wet $\left.\mathrm{wt} / \mathrm{m}^{2}\right)$ of functional (F)-form groups and their percentage (\%) for total biomass (TB) at Nachido and Odo Islands during the study period. S, Sheet form; F, Filamentous form; CB, Coarsely Branched form; TL, Thick Leathery form; JC, Jointed Calcareous form

\begin{tabular}{lccccrc}
\hline Sites & F-form & Summer & Autumn & Winter & Spring & Average (\% of TB) \\
\hline \multirow{4}{*}{ Nachido } & S & 9.72 & 0.98 & 1.34 & 3.40 & $3.86(0.96 \%)$ \\
& F & - & 0.12 & 1.49 & 12.42 & $3.51(0.87 \%)$ \\
& CB & 709.09 & 333.55 & 249.72 & 216.24 & $377.15(93.34 \%)$ \\
& TL & 8.71 & - & - & 0.55 & $2.32(0.57 \%)$ \\
\hline \multirow{5}{*}{ Odo } & JC & 27.38 & 10.90 & 30.67 & - & $17.24(4.27 \%)$ \\
& Total & 754.90 & 345.54 & 283.22 & 232.61 & $404.07(100.00 \%)$ \\
\hline & S & 29.30 & 16.34 & 1.60 & 178.36 & $56.40(20.83 \%)$ \\
& F & 0.52 & - & - & 34.16 & $8.67(3.20 \%)$ \\
& CB & 220.63 & 265.30 & 46.77 & 192.72 & $181.35(66.96 \%)$ \\
& TL & - & - & - & 37.28 & $9.32(3.44 \%)$ \\
& JC & 17.44 & 33.56 & 0.16 & 9.15 & $15.08(5.57 \%)$ \\
\hline
\end{tabular}

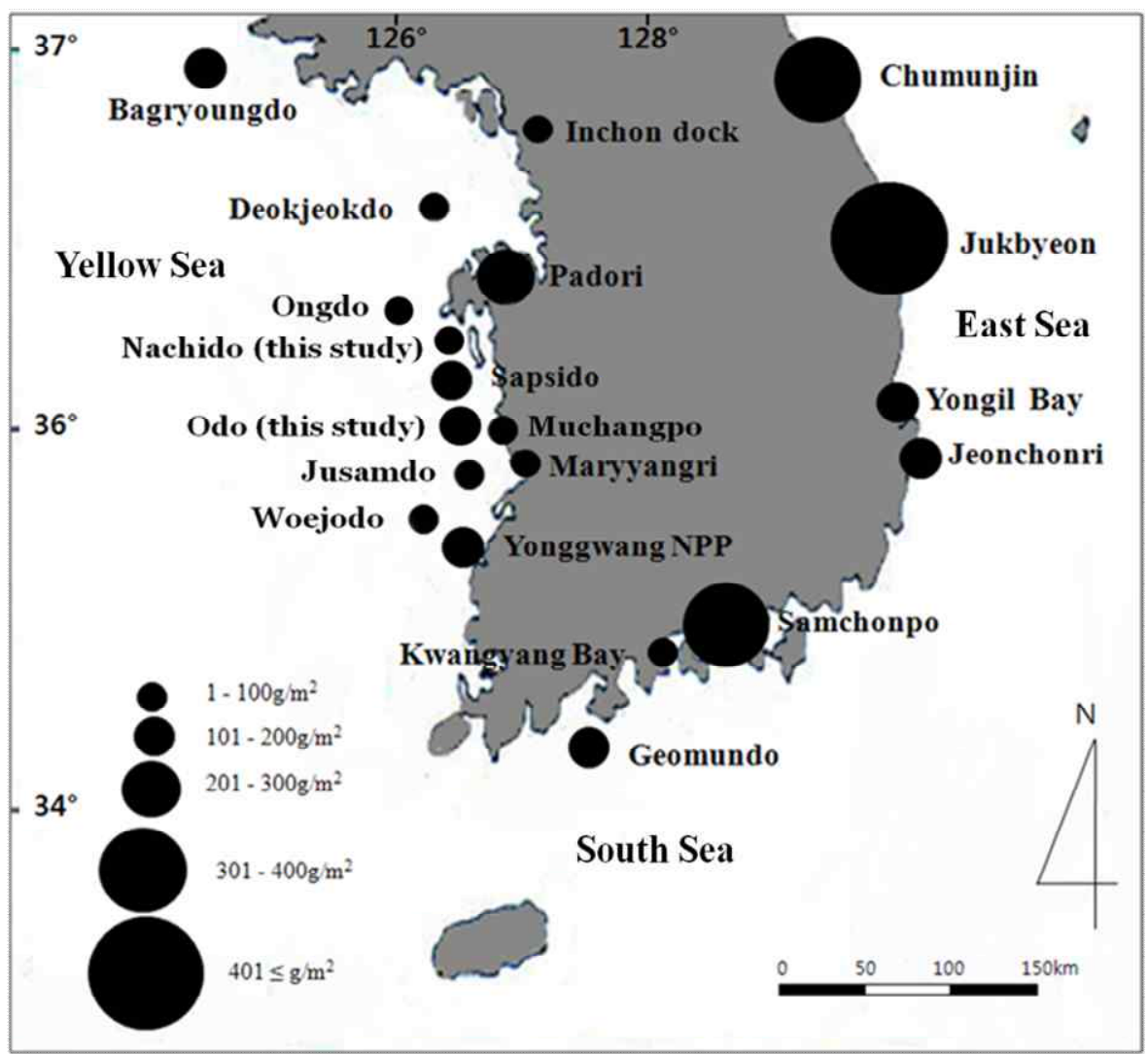

Fig. 3. Average annual biomass $\left(\mathrm{g}\right.$ dry $\left.\mathrm{wt} / \mathrm{m}^{2}\right)$ of seaweeds on the intertidal rocky shores of Korea.

temperate coastal ecosystems (Vasquez and Guerra, 1996); such changes are distinctive along the Yellow, East, and South Seas of the Korean Peninsula. Along the intertidal rocky shores of the Yellow Sea, seaweed biomass ranged from $22.00 \mathrm{~g}$ dry $\mathrm{wt} / \mathrm{m}^{2}$ to $295.70 \mathrm{~g}$ dry $\mathrm{wt} / \mathrm{m}^{2}$ in the vicinity of the Yonggwang Nuclear Power Plant (Kim and Huh, 1998) and fell below 100 g dry $\mathrm{wt} / \mathrm{m}^{2}$ along the Muchangpo and Maryangri coasts (Kim and Lee, 1985; Yoo and Kim, 1990). On offshore islands of the Yellow Sea, average annual biomasses of intertidal seaweed communities were $39.52 \mathrm{~g}$ dry wt $/ \mathrm{m}^{2}$ at Ongdo, $173.43 \mathrm{~g}$ dry $\mathrm{wt} / \mathrm{m}^{2}$ at Sapsido, and $97.46 \mathrm{~g}$ dry wt $/ \mathrm{m}^{2}$ at Jusamdo (Yoon and Boo, 1991; Choi et al., 2008; Wan et al., 2009). In the 
present study, seaweed biomasses in the intertidal zones of Nachido and Odo Islands were $84.32 \mathrm{~g}$ dry $\mathrm{wt} / \mathrm{m}^{2}$ and $107.50 \mathrm{~g}$ dry $\mathrm{wt} / \mathrm{m}^{2}$, respectively, which were greater than values observed at Ongdo, similar to those at Jusamdo, but less than those at Sapsido. Seaweed biomass was clearly lower along the coasts of the Yellow Sea (Fig. 3) than along those of the East and South Seas, Korea (Choi et al., 2008). Lower seaweed biomass along the coastal or offshore rocky shores of the Yellow Sea may have resulted from seawater turbidity caused by sediment suspension (Kim et al., 1995) and differences in dominant species (Choi et al., 2008; Wan et al., 2009).

Along the rocky intertidal zone of the Yellow Sea, Sargassum thunbergii is well established as the representative or key species (Yoo and Kim, 1990; Lee et al., 1997; Lee et al., 2000; Choi et al., 2008). The biomass of $S$. thunbergii accounted for $57.83 \%$ of the total seaweed biomass at Muchangpo, 56.88\% at Maryangri, 54.64\% at Jusamdo (Yoo and Kim, 1990; Choi et al., 2008), and 28.24-36.57\% at Nachido and Odo Islands (present study). These results indicate that the brown alga $S$. thunbergii is the key species in the Yellow Sea, regardless of location along coastal and offshore island rocky shores.

The seaweed biomass of marine ecosystems is also affected by the component algal taxon groups or functional-form groups (Johnston, 1969; Littler and Littler, 1980; Prathep, 2005). Along the rocky shores of island areas in the Yellow Sea, Korea, the dominant species were primarily brown algae, such as Laminaria japonica (at Bagroungdo; Beak et al., 2007) and Sargassum thunbergii (at Sapsido, Woejodo, and Jusamdo; Yoon and Boo, 1991; Choi et al., 2008), followed by red algae, such as Gloiopeltis furcata (at Deokjeokdo; Lee et al., 2007b) and Gelidium amansii (at Ongdo; Wan et al., 2009). In our survey, $S$. thunbergii (brown alga) and G. amansii (red alga) were the dominant species, together accounting for $43.47 \%$ of total biomass at Nachido and $51.27 \%$ at Odo. However, the taxon of the majority of seaweed species (with average annual biomass $>10 \mathrm{~g}$ wet $\mathrm{wt} / \mathrm{m}^{2}$ ) on the two islands was red algae (four and five species at Nachido and Odo Islands, respectively), and the total biomasses of the two taxa (brown and red algae) were very similar. In addition, coarsely branched-form seaweeds were dominant along the rocky shores of both islands, i.e., $S$. thunbergii, $G$. amansii, and $C$. ocellatus at Nachido Island and $S$. thunbergii and $G$. amansii at Odo Island. Thus, the environmental conditions of the two islands are relatively stable in functional-form and taxongroup composition because neither sheet or fila- mentous functional-form seaweeds nor ephemeral green algae were abundant.

Biodiversity and abundance of functional-form seaweeds are used as important parameters representing environmental conditions such as sediment characteristics, water turbidity, and disturbance (Sohn, 1987; Yoo et al., 2007). The relative proportion of functional-form group seaweeds has primarily been examined in terms of the number of species within each group (Sohn, 1987) and more recently in terms of the biomass of each functional group (Wan et al., 2009). Along the coastal areas of the Yellow Sea, coarsely branched seaweeds were the major group in terms of species number, comprising $42.00 \%$ to $52.73 \%$ of all species (Hwang et al., 1996; Lee et al., 2007a; Yoo et al., 2007; Choi et al., 2008). Sohn (1987) reported that sheet and filamentous groups exhibited relatively high proportions, varying from $31 \%$ to $59 \%$, due to high water turbidity in the Yellow Sea. Most rocky shores of the Yellow Sea, such as those at the Taean Peninsula and Yeonpyeongdo Islets, are dominated by green algae or crustose coralline algae occurring in polluted or disturbed environments (Lee et al., 2007a; Yoo et al., 2007; Choi et al., 2008). However, in the present study, the proportion of coarsely branched seaweed biomass was higher at Nachido (93.34\%) than at Odo Island (66.96\%), where the proportion of sheet seaweeds was greater, comprising about $20.83 \%$ of total biomass. Thus, we concluded that Nachido Island offered more stable environmental conditions compared with Odo Island, which was dominated by filamentous and sheet-like foliose seaweeds such as Scytosiphon lomentaria, Dumontia simplex, Urospora penicilliformis, and Porphyra tenera in the spring. In terms of functionalform composition, however, the two offshore islands exhibit better environmental conditions compared with shallow and highly turbid coastal areas where sheet- and filamentous-form seaweeds are common (Sohn, 1987).

\section{Acknowledgements}

We thank the members of the Marine Biological Laboratory, Wonkwang University, for providing help with field and laboratory work. This study was financially supported by Wonkwang University in 2010.

\section{References}

Arévalo R, Pinedo S and Ballesteros E. 2007. Changes in the composition and structure of Mediterranean rocky- 
shore communities following a gradient of nutrient enrichment: Descriptive study and test of proposed methods to assess water quality regarding macroalgae. Mar Poll Bull 55, 104-113.

Baek IM, Hwang MS, Lee JW and Kim JI. 2007. The macroalgal community of Bagryoungdo island in Korea. Algae 22, 117-123.

Ballesteros E, Torras X, Pinedo S, Garcı'a M, Mangialajo L and de Torres M. 2007. A new methodology based on littoral community cartography dominated by macroalgae for the implementation of the European Water Framework Directive. Mar Poll Bull 55, 172-180.

Choi CG and Huh SH. 2008. Composition of marine algal community at the intertidal zone in Gwangyang Bay, South Sea, Korea. J Kor Fish Soc 41, 201-207.

Choi CG, Takeuchi Y, Terawaki T, Serisawa Y, Ohno M and Sohn CH. 2002. Ecology of seaweed beds on two types of artificial reef. J Appl Phycol 14, 343-349.

Choi HG, Lee KH, Wan XQ, Yoo HI, Park HH, Kim JH and Chung IK. 2008. Temporal variations in seaweed biomass in Korean coasts: Woejodo and Jusamdo, Jeonbuk. Algae 23, 335-342.

Díez I, Santolaria A and Gorostiaga JM. 2003. The relationship of environmental factors to the structure and distribution of subtidal seaweed vegetation of the western Basque coast (N Spain). Estuar Coast Shelf Sci 56, 1041-1054.

Eklof JS, Torre Castro M, Adelskold L, Jiddawi NS and Kautsky N. 2005. Differences in macrofaunal and seagrass assemblages in seagrass beds with and without seaweed farms. Estuar Coast Shelf Sci 63, 385-396.

Hay ME. 1994. Species as 'noise' in community ecology: do seaweeds block our view of the kelp forest? Trends Ecol Evol 9, 414-416.

Hwang EK, Park CS, Sohn CH and Koh NP. 1996. Analysis of functional form groups in macroalgal community of Yonggwang vicinity, western coast of Korea. J Kor Fish Soc 29, 97-106.

Johnston CS. 1969. The ecological distribution and primary production of macrophytic marine algae in the Eastern Canaries. Int Rev Ges Hydrobiol 54, 473-490.

Kim YH, Yoon HJ and Yoo JS. 1995. Species composition and biomass of marine algal community on the midwestern coast of Korea. J Plant Biol 38, 389-398.

Kim YH and Huh SH. 1998. Species composition and biomass of marine algal community in the vicinity of Yonggwang nuclear power plant on the west coast of Korea. J Korean Fish Soc 31, 186-194.

Kim YH and Lee IK. 1985. The structure analysis of intertidal algal community in Muchangpo, western coast of Korea. Kor J Bot 28, 149-164.

Ko YW, Sung GH, Yi CH, Kim HH, Choi DM, Ko YD, Lee WJ, Koh HB, Oak JH, Chung IK and Kim JH. 2008.
Temporal variations of seaweed biomass in Korea coast: Munseom, Jeju island. Algae 23, 295-300.

Konar B, Iken K, Edwards M. 2009. Depth-stratified community zonation patterns on Gulf of Alaska rocky shores. Mar Ecol 30, 63-73.

Lee JW, Oh BG and Lee HB. 1997. Marine algal flora and community of Padori area in the Taean peninsula, the west coast of Korea. Kor J Phycol 12, 131-138.

Lee JW, Oh BG and Lee HB. 2000. Marine benthic algal community at Padori, west coast of Korea. Algae 15, 111-117.

Lee KH, Yoo HI and Choi HG. 2007a. Seasonal community structure and vertical distribution of medicinal seaweeds at Kkotji in Taean Peninsula, Korea. Algae 22, 209-219.

Lee WJ, Hwang MS, Beak JM, Lee JW and Kim JI. 2007b. Primary survey on algal community of Gyounggi bay for restoration. Algae 22, 201-207.

Lee YP and Kang SY. 2001. A catalogue of the seaweeds in Korea. Cheju National University Press, Cheju, 662.

Littler MM and Littler DS. 1980. The evolution of thallus form and survival strategies in benthic marine macroalgae: field and laboratory tests of a functional form model. Am Nat 116, 25-44.

Littler MM and Littler DS. 1984. Relationships between macroalgal functional form groups and substrata stability in a subtropical rocky-intertidal system. Mar Biol 74, 13-34.

Neto AI. 2001. Macroalgal species diversity and biomass of subtidal communities of São Miguel (Azores). Helgol Mar Res 55, 101-111.

Phillips JC, Kendrick GA and Lavery PS. 1997. A test of a functional group approach to detecting shifts in macroalgal communities along a disturbance gradient. Mar Ecol Prog Ser 153, 125-138.

Piazzi L, Pardi G, Balata D, Cecchi E and Cinelli F. 2002. Seasonal dynamics of a subtidal north-western Mediterranean macroalgal community in relation to depth and substrate inclination. Bot Mar 45, 243-252.

Pinedo S, Garcia M, Satta MP, Torres M and Ballesteros E. 2007. Rocky-shore communities as indicators of water quality; a case study in the north-western Mediterranean. Mar Poll Bull 55, 126-135.

Prathep A. 2005. Spatial and temporal variations in diversity and percentage cover of macroalgae at Sirinart marine national park, Phuket Province, Thailand. Science Asia 31, 225-233.

Sohn CH. 1987. Phytogeographical characterization and quantitative analysis of algal communities in Korea. Ph. D. Thesis. Chonnam National University, Kwang-ju, Korea, 104.

Steneck RS and Dethier MN. 1994. A functional group approach to the structure of algal-dominated com- 
munities. Oikos 69, 476-498.

Terawaki T, Hasegawa H, Arai S and Ohno M. 2001. Management-free techniques for restoration of Eisenia and Ecklonia beds along the central Pacific coast of Japan. J Appl Phycol 13, 13-17.

Vadas RL and Steneck RS. 1988. Patterns of deep water benthic algae in the Gulf of Maine. J Phycol 24, 338346.

Vásquez JA and Guerra N. 1996. The use of seaweeds as bioindicators of natural and anthropogenic contaminants in northern Chile. Hydrobiologia 326/327, 327-333.

Wan XQ, Park HH, Yoo HI and Choi HG. 2009. Temporal variations in seaweed biomass and coverage in Korean coasts: Ongdo, Chungnam. Fish Aqua Sci 12, 130-137.
Yoo HI, Lee JH, Lee KH, Beak SH, Heo YB, Noh HS and Choi HG. 2007. Summer marine algal floras and community structures in Taean Peninsula, Korea. J Kor Fish Soc 40, 210-219.

Yoo JS and Kim YH. 1990. Structure analysis of intertidal algal community at the coast of Taean thermal power plant, Korea. Algae 18, 311-320.

Yoon MY and Boo SM. 1991. Flora and zonation of marine plants at the littoral area of Sapsido island on the Yellow sea of Korea. Kor J Phycol 6, 145-156.

(Received 30 September 2010; Revised 8 November 2010; Accepted 16 November 2010) 